\title{
Salones darianos: fotografia, arte y literatura en la crónica modernista
}

\author{
Darío's Salons: Photography, Art and Literature \\ in the Modernist Ghronicle
}

\author{
Luis Alberto Salas Klocker \\ Universidad de Buenos Aires \\ Universidad Nacional de Tres de Febrero, Argentina \\ luissalas1989@gmail.com
}

\section{RESUMEN}

Partiendo de lo que la crítica ha llamado los salones darianos, esto es, las crónicas que Darío le dedicó a las distintas exposiciones de arte que visitó, el presente trabajo se propone reflexionar sobre el papel que jugó la imagen en el proyecto cultural del modernismo. En el entresiglo, la reproducción técnica de la imagen irrumpió en la prensa y en los salones de arte. Esto fue percibido por Darío, quien exploró la relación de la imagen fotográfica con las incipientes industrias culturales. Menos conocido que las revistas Mundial y Elegancias, el primero de los proyectos darianos que incluía una fuerte presencia de imágenes, esto es, el "Suplemento Semanal Ilustrado" del diario La Nación, tensiona la matriz letrada de la crítica literaria y abre nuevos horizontes en los estudios del modernismo. Si bien dicho suplemento no estaba directamente bajo su dirección, sí coincide con uno de los momentos altos de su carrera en el diario argentino. Darío fue por un tiempo el máximo animador de este suplemento, por lo que se lo puede leer como un modelo a escala de las operaciones darianas en pos de un campo artístico ampliado.

\section{Palabras clave}

Modernismo, revistas culturales, fotografía, giro pictórico, arte.

\section{ABSTRACT}

Based on what it has been called the salones darianos, that is, the chronicles that Darío wrote about several art exhibitions that he visited, this work aims to reflect on the role that the image played in the cultural project of modernismo. At the turn of the century, the image's technological reproducibility broke into both the press and art salons. This was perceived by Darío, who explored the relationship of the photographic image with the incipient cultural industries. Less known than Mundial and Elegancias magazines, the first of Darío's projects that included a strong 
presence of images, that is, the "Suplemento Semanal Ilustrado" of La Nación, goes beyond the lettered bias of literary criticism and opens new horizons to modernismo studies. Although this magazine was not directly under his direction, it does coincide with one of the high points of his career in the Argentine newspaper. Darío was for a time the main animator of this magazine, so his performance can be read as a scale model of his operations in pursuit of an expanded artistic field.

\section{KEYWORDS}

Modernismo, cultural magazines, photography, pictorial turn, art.

RECEPCIÓN: 28/06/2020

ACEPTACIÓN: 08/09/2020

\section{Darío ante la crónica}

e las experiencias de Darío con la prensa ilustrada, tradicionalmente se rescatan dos momentos: 1) la revista Elegancias, publicación dedicada a la moda y orientada al público femenino, al frente de la cual Darío estuvo desde 1911 hasta 1914; y 2) la revista Mundial, que por los mismos años le sirvió como plataforma de propaganda cultural hispanoamericana en París. A estos dos hitos podríamos agregarle las ilustraciones que acompañaron algunos de los perfiles que luego serían parte de Los Raros, así como el bajorrelieve dorado con su rostro en la portada del libro, retrato del artista argentino Eduardo Schiaffino. Sin embargo, no fueron estas sus primeras aproximaciones al trabajo editorial con la imagen. Darío llegó a dirigir dos revistas ilustradas, pero su lugar de partida, lo sabemos, fue la literatura.

Su primera experiencia intensiva con un medio gráfico se dio en el "Suplemento Semanal Ilustrado" del diario La Nación. Si bien nunca fungió como su director - ya que esta tarea recaía sobre el uruguayo Julio Piquet-, sí fue su principal animador durante el primer periodo del impreso. Entre septiembre de 1902 y diciembre de 1903, el "Suplemento" publicó veintinueve crónicas darianas, esto es, más de las dos terceras partes del total de sus colaboraciones en el diario. La mayoría de esas crónicas luego sería recogida en los volúmenes Parisiana y Opiniones, pero sin las imágenes que las acompañaron originalmente. Tal decisión editorial desmontó el particular efecto de sentido que la conjunción de imagen y texto producía, por lo que una vuelta al archivo nos permitiría recuperar en toda su densidad aquello que Roland Barthes definió como "un complejo de mensajes concurrentes, cuyo centro es la fotografía y cuyos contornos están representados por el título, la leyenda, la disposición en la página, y de manera más abstracta, pero no menos 'informante', el propio nombre del periódico" (Barthes, 2016: 86). 
Las revistas ilustradas a las que nos referimos son objetos culturales propios del fin de siglo. En su estudio sobre la prensa gráfica de ese periodo, Eduardo Romano propone rescatar el rol que tuvo el periodismo ilustrado en la modernización literaria, es decir, en la construcción de una autoridad específica en tanto discurso autónomo. Para Romano, habría dos momentos dentro de este proceso, el primero de los cuales coincide con la tesis de la autonomización literaria que Julio Ramos desarrolla en Desencuentros de la modernidad en América Latina. Durante aquel periodo, que corresponde con la fundación del diario La Nación en 1870, se incorporó el telégrafo transatlántico, se implementó el pago por las corresponsalías con grandes escritores del mundo y, principalmente, se abandonó el viejo modelo de la prensa partidaria o facciosa y se adoptó el modelo contemporáneo de periodismo de información. Un segundo impulso en ese proceso modernizador vino a mediados de la década de 1880 y se iría radicalizando hacia fines de siglo con el surgimiento de los medios gráficos. Estos, en palabras de Romano, se convirtieron en la "vanguardia del periodismo" (Romano, 2005: 49) y constituyeron así la otra cara de la modernización burguesa.

El año es 1895, año del surgimiento del género del magazine tal como lo conocemos hoy. Esto sólo pudo ocurrir tras el desarrollo de las tecnologías del grabado y la litografia, las cuales constituyen lo que la crítica llama el segundo proceso de industrialización de los medios gráficos (Tell, 2009: 142). El primero concuerda con el desarrollo de las tarjetas de visita con retratos, una suerte de antecedente de la tarjeta postal. Las mencionamos aquí porque éstas tendrán su rol en la configuración de las nuevas figuras de autor que emergieron en los últimos años del siglo XIX. Para la región rioplatense, el mejor ejemplo de estos magazines es la revista Caras y Caretas, fundada primero en Montevideo y luego trasladada a Buenos Aires. De acuerdo con Romano, la ampliación de los públicos lectores que llevó adelante esta revista fue posible gracias al "alarde heteroglósico" (Romano, 2005: 433) y a la "táctica transclasista" (Romano, 2005: 430) subyacente en la adaptación de materiales para todos los gustos. Esto representó el pasaje del modelo francés del periodismo al modelo estadounidense, que preconizaba la amalgama de géneros y el escaso tiempo de lectura requerido para cada nota.

El "Suplemento Semanal Ilustrado" fue la apuesta del diario La Nación por competir en dicho segmento. ${ }^{1}$ Se publicaron un total de 365 números a lo largo de 7 años,

1 "El "Suplemento Ilustrado" nace el jueves 4 de septiembre de 1902 con la expectativa - anunciada por el mismo periódico el día anterior - de que "las artes gráficas [den] forma nueva y más perfecta á la acción del periodismo". Agrega el anuncio que este segmento experimental de La Nación "será conservado en manos de los suscriptores como se conservan y se coleccionan las revistas ilustradas" (véase Caresani y Schmigalle, 2017: 51). Poco tiempo después, La Nación "anticipa a sus lectores una importante modificación en sus suplementos bajo el título 'Nuestro suplemento ilustrado - El número de mañana - Cambio de formato 
desde el 4 de septiembre de 1902 hasta el 9 del mismo mes, pero del año 1909. En sus primeros 143 números mantuvo dimensiones de revista - con variaciones - para luego adoptar las medidas de la sábana del diario. Salía todos los jueves, era gratuito para los suscriptores del diario y costaba ocho centavos si se compraba suelto. Si lo comparamos con los veinte centavos que costaba Caras y Caretas, era bastante económico. Además, incluía un vastísimo despliegue de publicidad y de imágenes, tanto fotografias como ilustraciones. La parte escrita estaba dedicada a la cobertura de moda, literatura, la realeza europea, algo de divulgación científica y varias notas dedicadas al arte. Son éstas las que nos interesan por las posibilidades que la prensa gráfica le abría al periodismo cultural, especialmente cuando el cronista se veía apabullado por la cantidad de obras presentadas en las exposiciones a las que asistía. El tópico de la abundancia es una constante en esos textos. Del total de crónicas que Darío publicó en tal sección, cinco están explícitamente dedicadas al arte: tres versan sobre el Salón de Bellas Artes de París, una sobre el escultor argentino Rogelio Yrurtia y otra sobre la pintora inglesa Evelyn De Morgan. Podríamos agregar una más, la referente a la tarjeta postal, porque, en su propia materialidad, las revistas ilustradas representaron una toma de postura sobre el rol que ocuparía la imagen — tanto la "original" como la técnicamente reproducida- en las nuevas formas de la cultura.

Las crónicas sobre las exposiciones de arte, aquellas que Rodrigo Caresani - haciendo una analogía con Charles Baudelaire - llama los salones darianos (Caresani, 2015: 144), constituyen un género en sí mismas. Son alrededor de veinticinco crónicas las que Darío escribió a lo largo de su carrera y que estuvieron dedicadas a este tipo de muestras. En 1895, el diario La Prensa de Buenos Aires publicó siete crónicas sobre el Salón del Ateneo en la capital argentina. En 1899, ya en España, Darío narra en dos crónicas para La Nación su experiencia en la exposición de Bellas Artes en

- 32 páginas': 'El suplemento ilustrado que recibirán mañana todos los suscriptores de LA NACIÓN y que deben reclamar á los vendedores los que adquieran números sueltos, constará de 28 páginas, casi todas con texto e ilustraciones, sin contar las cuatro de la cubierta, en la que también figurará siempre algún grabado de actualidad. Desde que iniciamos la publicación del suplemento ilustrado, como lo hemos dejado entrever en publicaciones anteriores, son muchos los que nos han manifestado el deseo de que redujésemos el formato para que los números pudiesen coleccionarse con más facilidad y que aumentásemos el material de lectura para darles mayor interés. Estos consejos han coincidido con la estrechez del espacio en LA NACIÓN, á causa del aumento de los avisos, y con la enorme aglomeración de materiales que nos ha obligado á agregar á los suplementos ilustrados algunos suplementos literarios. Teniendo en cuenta las indicaciones recibidas y las conveniencias del diario y del público, hemos resuelto refundir en uno solo los dos suplementos, disminuir el formato, aumentar considerablemente el número de páginas y agregar la correspondiente carátula. El nuevo número que aparecerá regularmente todos los jueves viene á ser doble del que hemos publicado hasta ahora, lo que no quiere decir que no sea susceptible de aumento"' (véase Caresani y Schmigalle, 2017: 52). 
Madrid. En 1900, en el marco de la Exposición Universal de París, una crónica cubre la exposición conmemorativa del arte francés en el Palacio de Bellas Artes; asimismo, en su viaje a Italia, refiere su visita a la Pinacoteca de Turín. Desde 1901, el género se estabiliza y se concentra en los dos salones de París, el Salón de la Société Nationale des Beaux Arts y el Salón de la Société des Artistes Français. Es así que hasta 1904, inclusive, Darío le dedicará entre tres y cuatro crónicas a los distintos salones, haciendo especial énfasis en la participación de los artistas hispanoamericanos. En 1905 Darío se encontraba en España, por lo que no tenemos crónicas de las muestras; pero en 1906 las retoma con una sola entrega, igualmente para el diario La Nacion. ${ }^{2}$

Las conclusiones de Laura Malosetti Costa sobre las crónicas de La Prensa son perfectamente trasladables a los demás salones darianos: se trata de textos programáticos que pueden ser ubicados en el eje de los distintos momentos del proyecto dariano (Malosetti, 2001: 380). La lógica y la coherencia internas de la serie esbozada anteriormente apenas se ven perturbadas en las tres crónicas del año 1903, justo aquellas que fueron publicadas en el "Suplemento Semanal Ilustrado" del diario La Nación. La imagen, en efecto, altera la sintaxis de un género que sorprende por la estabilidad dentro del re-

\footnotetext{
${ }^{2}$ La serie sugerida ha sido recopilada en distintos volúmenes. Para las crónicas de La Prensa, "El Salón” (21/10/1895), "El Salón. II” (22/10/1895), "El Salón. III” (23/10/1895), "El Salón. IV" (25/10/1895), "El Salón. V" (27/10/1895), "El Salón. VI" (01/11/1895) y "El Salón. VII" (10/11/1895), ver Caresani (2015). Las crónicas españolas son "De Rubén Darío: exposición de Bellas Artes: I" (06/06/1899) (Darío, 1901a: 143-152; Darío, 1998: 193-199) y "De Rubén Darío: exposición de Bellas Artes: II” (22/06/1899) (Darío, 1998: 409-412). Sobre la Exposición Universal de París, "De Rubén Darío: la exposición: los edificios: el gran palacio de Bellas Artes: diez años de arte: los artistas de mi devoción" (04/06/1900) (Darío, 1901b: 44-51). Sobre la Pinacoteca de Turín, "De Rubén Darío: diario de Italia: Turín” (22/10/1900) (Darío, 1901b: 159-169; Darío, 2013: 141-147). Para los Salones de París, "De Rubén Darío: el salón: Société Nationale des Beaux-Arts: vernissage: la escultura" (27/05/1901) (Darío, 1902: 291-296; Darío, 2004: 255-263), “De Rubén Darío. El Salón. Société Nationale des Beaux-Arts. La pintura. II" (02/06/1901) (Darío, 1977: 100-103), "En el 'Salón': los hispanoamericanos" (06/06/1901) (Darío, 2006: 69-77), "De Rubén Darío: el Salón: Société Nationale des Beaux Arts: (especial de La Nación)" (04/06/1902), "De Rubén Darío: el Salón: Société Nationale des Beaux Arts: (especial para La Nación): II" (08/06/1902) y "De Rubén Darío: el Salón: Société des artistes français: (especial para La Nación): III" (17/06/1902) (Darío, 1902: 259-276; Darío, 2004: 181-238). Las crónicas publicadas en el suplemento son: "Salón I: el de 'Beaux Arts"” (28/05/1903) (Darío, 2006: 254-260), "Salón: el de 'Beaux Arts"” (11/06/1903) (Darío, 2006: 275-280) y "Salón. El de 'Beaux Arts'. El de la 'Société des Artistes Français"” (18/06/1903) (Darío, 2006: 281-301). Otras crónicas de los salones de París: "El Salón: Société Nationale des Beaux Arts: I" (15/05/1904) (Darío, 1977: 194-197), "El Salón: 'Société Nationale des Beaux Arts': II" (29/05/1904), "El Salón: 'Société Nationale des Beaux Arts': III" (30/05/1904) y "Los hispanoamericanos en el salón de París" (08/06/1904) (Darío, 1907: 221-249). Finalmente, "Los salones de 1906: I. Société Nationale des Beaux Arts" (30/05/1906) (Darío, 2006: 518-527).
} 
pertorio dariano. Desde las elocuentes crónicas del Salón del Ateneo hasta la última y desencantada crónica de los salones de París, Darío ensaya un lenguaje que explicita la interferencia de códigos, que de manera deliberada deja penetrar la lógica del lenguaje visual en la del lenguaje escrito. Caresani reconoce algunas de estas interferencias en, por ejemplo, la dominancia de las secuencias descriptivas; en la sintaxis acumulativa y paratáctica que, casi sin transición, aborda un cuadro tras otro; y, más significativamente, en una "retórica [que] tiende a cancelar la dimensión temporal en favor de la analogía entre 'lenguaje' y 'espacio recorrido"' (Caresani, 2015: 141). A más de esta interferencia entre códigos, otras particularidades de las crónicas dedicadas a exposiciones de arte son: 1) la explicitación del gusto personal como criterio de selección ("En tan gran cantidad de cuadros, no me detendré sino en los que al paso llaman la atención, sin clasificaciones, ni géneros. Todo será según el cúmulo de mis notas" [Darío, 1998: 410]); 2) la atención prestada a la sociabilidad que las exposiciones propician ("Después será el ver los cuadros y las estatuas: el primer día, el del vernissage, es para los cuadros vivos y las estatuas de carne" [Darío, 2004: 255]); 3) la lamentación sin contemplaciones por el estado actual del arte ("Aquí uno recorre salas y salas y apenas se siente atraído, rara vez, por una obra que merezca unos instantes de contemplación" [Darío, 2004: 184]); y, finalmente, 4) la retórica prescriptiva del conocedor que guía y aconseja al lego ("En la vigésima no dejéis de inclinaros ante el Veronese y Tiépolo, y en la última soportad las varias batallas de Huchtemburg" [Darío, 2013: 142]).

La imagen interfiere en algunas de estas características. Surge, entonces, la pregunta metodológica. ¿Cómo leer este "complejo de mensajes concurrentes" (Barthes, 2016: 86)? Tal inquietud atraviesa tanto los estudios de la imagen como aquellos que desde la literatura se proponen trabajar con la materialidad de objetos que aúnan los códigos visual y lingüístico, sin por ello perder de vista una lectura cercana de los textos. Annick Louis sugiere considerar los múltiples contextos que se superponen en la publicación de revistas ilustradas, siendo los más útiles para entender la estrategia dariana en estas crónicas los contextos de publicación y de lectura. Mientras el primero tiene que ver con la puesta en página del texto y de la imagen (Louis, 2014: 35) —o, para decirlo con W. J. T. Mitchell, de la imagentexto (Mitchell, 2009: 17)-, el segundo se refiere a cómo la revista interpela a sus lectores en el pacto que establece con ellos para ser leída (Louis, 2014: 43). No la recepción efectiva de los textos - material para la sociología-, sino cómo éstos piden ser abordados. Es evidente que, en ambos campos, las revistas ilustradas, en general, y el "Suplemento" de La Nación, en particular, resultaban innovadores.

Este tipo de fenómenos hoy en día nos parecen perfectamente normales por lo intermedial de la cultura contemporánea, pero en su momento representaron una perturbación de la concepción letrada de la lectura. En ese sentido, es significativo el concepto que el propio diario La Nación tenía de su suplemento. De acuerdo a sus 
propias palabras, el "Suplemento Semanal Ilustrado" se vuelve posible por el aporte que las tecnologías de la imagen le podían dar al "Suplemento Literario", una suerte de complemento de aquél. ${ }^{3}$ De esta sinergia surge el "Suplemento" ilustrado. Darío participa en sus primeras dos etapas, dado que en la tercera el texto desaparece por completo y es reemplazado por la pura imagen. De forma paradójica, a pesar de la fugacidad del "Suplemento Literario", el número de memoria institucional publicado con motivo del centenario del diario La Nación recalca, de modo enfático, el carácter literario, esto es, letrado, del "Suplemento", en detrimento de aquello que marcó de manera más duradera y significativa este objeto cultural, su dimensión gráfica, léase, su pulsión plebeya.

Lo cierto es que, en 1904, coincidiendo con el abrupto cese de las colaboraciones darianas en el "Suplemento", el desarrollo de la técnica de fotograbado permitió que el uso de la imagen fuera adoptado por las páginas del diario, mermando así las incumbencias de la revista ilustrada. Desde ese momento, la imagen acompañaría igualmente la contingencia de las noticias cotidianas y "banales", por lo que sería necesario redefinir las funciones de esta sección. Si la reproducción técnica de la imagen puede estar al servicio de la coyuntura, el suplemento semanal - cualquiera que éste fuera - no podía seguir ocupándose de temas efímeros, justamente por su carácter excepcional. Por ende, los roles se trastocan y el "Suplemento" pasa a ser el depósito de los temas "trascendentes". Así, se entiende el énfasis que La Nación hace sobre la naturaleza literaria del suplemento. Éste es el periodo en el que Darío vuelve a publicar en las columnas del diario, mientras que en el "Suplemento" asciende la figura de Max Nordau.

\section{Darío ante la imagen}

Analicemos la primera crónica del "Suplemento" que Darío le dedica al Salón de Bellas Artes, publicada el 28 de mayo de 1903. El texto ficcionaliza, a los ojos del lector, una discusión entre Darío y un amigo mientras recorren la exposición. La "enumeración morosa del narrador hiperestésico" (Caresani, 2018: 570) se suspende y es reemplazada por disquisiciones sobre las particularidades del arte del retrato moderno. Las tesis del interlocutor de Darío se refieren a una cierta propensión a la búsqueda infructuosa del alma del retratado por parte de los artistas, así como a su

${ }^{3}$ El "Suplemento Literario" fue un efímero proyecto del diario La Nación estrictamente contemporáneo a la aparición del "Suplemento Semanal Ilustrado". En este medio, Darío publicó una crónica, "De Rubén Darío. El cementerio de los perros" (11 de octubre de 1902), que luego fue recopilada en Parisiana bajo el título de "Duelos cínicos". 
predilección por el detalle significativo antes que por la totalidad del ser en cuestión. ${ }^{4}$ Darío concuerda con el diagnóstico de su amigo, pero prefiere, antes que el tema de los retratistas modernos y sus búsquedas, la constatación de que "subsisten los justos procedimientos de otras épocas con idénticos resultados, de manera, que la realización artística se impone" (Darío, 2006: 258-259). La deixis en la crónica configura una escena de lectura en la que la vista está constantemente obligada a conectar el texto y la imagen, ya que ésta no aparece "traducida" en el texto por los recursos tradicionales de tratamiento de la imagen (como podría ser la ékfrasis), sino que se presenta como fragmentos del pensamiento dariano plasmados en la página.

4 "La época actual concibe, por sus pintores, una elegancia hecha de reticencia en todo el ser, y en esa elegancia el alma tiene su parte. Antes decorativa, la exterioridad humana significaba, por la suntuosidad de los trajes y el brillo de los rostros en fiesta, felices de brillar, felices de vivir, y el ser interior permanecía secreto; al menos, el arte plástico no pretendía enunciar lo que había bajo la máscara de carne, a menos que el alma no se encontrase identificada por la naturaleza. Casi todas las efigies de antes no son poderosos motivos de ensueño, porque su anónimo es absoluto y nosotros escribimos en ellas lo que guardamos en nosotros mismos. Esas sombras, esos relieves, esas luces son los temas armoniosos de nuestras interpretaciones personales. El retrato moderno ha modificado profundamente las relaciones entre modelo y pintor y entre pintor y espectador. Es el alma lo que se busca, y hay una operación magnética en todo bello retrato moderno. Pero, mientras más buscada es el alma, más quiere obrar la sugestión, y más se niega el alma a aparecer; se repliega, se vela, no quiere entregar de ella sino lo que quiere hacer conocer, y esta lucha entre la investigación del pintor y el pudor del alma transforma el arte plástico y da al retrato una especial expresión de inquietud. El dibujo y el color toman otros aspectos, ya no es la realidad del ser representado un fin, sino un medio de la pintura [...] Las existencias y las sensibilidades modernas fluctúan sin escogerse una dominante, y se asimilan todas las inclinaciones sin restringirse a ninguna. Examinemos los retratos contemporáneos, no la muchedumbre de los que aplican a los seres de hoy las fórmulas de antes, sino los raros que verdaderamente hayan revelado una manera conforme con la psicología presente. Todos son reticentes, hundidos en la penumbra, o atenuados en una actitud descuidada, perfilados, prestos a desaparecer, sin pensar jamás en el espectador y rehusando la mirada. La manera de dar los toques es más literaria que pictórica. Los valores desempeñan un papel principal. La sombra, la luz, dos o tres grises, una nota obscura o rosada, y es todo el tema, y de ahí todo el tema de variaciones sutiles que expresan el ser por el rostro y las manos, en la simplificación del traje inglés, en la neutralidad del traje de paseo realzado por una flor o por el brillo furtivo de una joya, o por el pliegue negligente de un lazo. Nunca se ha gustado más del rasgo sobriamente significativo, del estilo buscado en la actitud familiar, la definición del personaje por una gran línea decorativa, de inflexión según el contorno y que limita sin insistencia, con flexibilidad y encanto. Las faces, donde se concentra toda la volición del individuo; las manos, donde se expresa toda su vacilación, parecen aclarar la sombra con su reflejo de pálida cera. La luz se impone menos a los relieves de los seres, que lo que resalta de su vitalidad oculta; llega a ser una emanación psíquica, mucho más que una resultante natural de la óptica” (Darío, 2006: 257-258). 


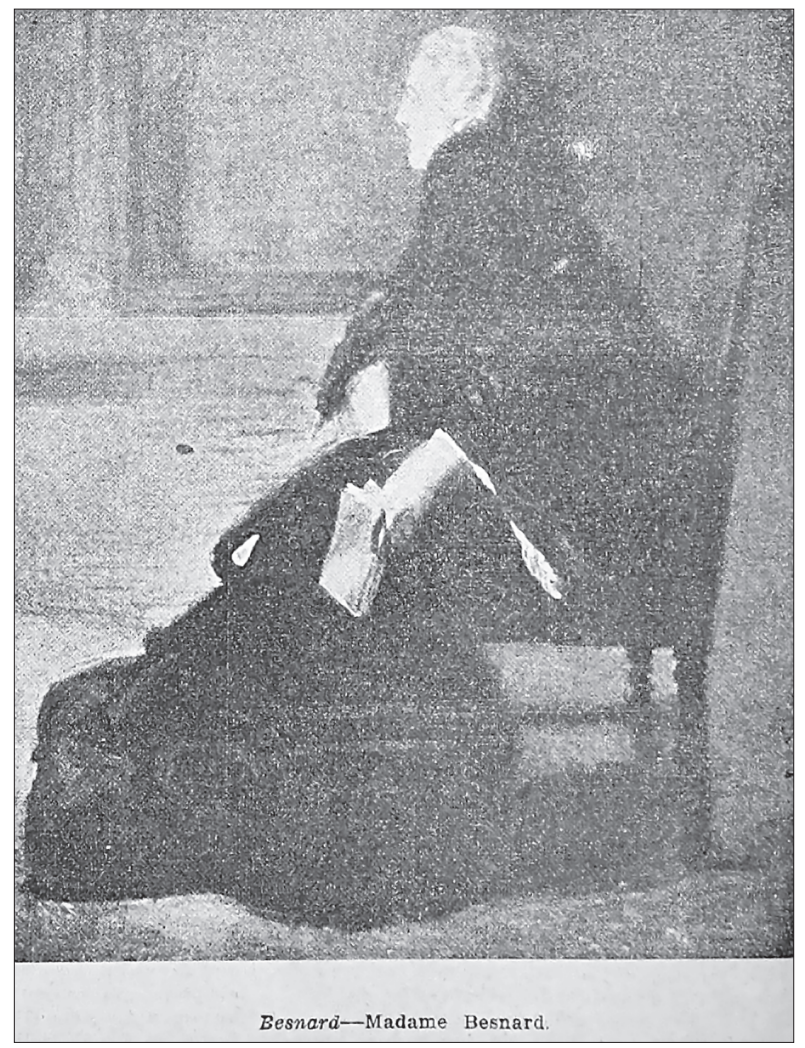

Mas, dejemos las disquisiciones y contemplemos. Detengámonos ante el retrato de Mme. Besnard por su marido, que, aunque muy diferente en ciertos puntos técnicos, hace recordar el admirable retrato que de su madre hizo Whistler (Darío, 2006: 259). Imagen propia.

Tampoco puede decirse que, como marcaba Barthes para el periodo previo al de la omnipresencia de la imagen, éstas vienen a ilustrar las palabras de la crónica (Barthes, 2016: 94). En esta crónica - sin duda, la más lograda en tanto imagentexto - la palabra es concurrente con la imagen, ya que gracias a ella el cronista encuentra el espacio para el despliegue de su razonamiento. La supuesta discusión ocupa toda la parte central de la crónica y, si se piensa como estrategia retórica —un diálogo, en definitiva - podemos reconstruir la dialéctica de una teoría del arte. Varios indicios en el texto parecerían indicar que aquello de lo que se está hablando es de la conflictiva relación entre pintura y fotografía, lo cual se refuerza con la centralidad que se otorga a la discusión sobre el retrato, ese campo en disputa entre ambas disciplinas. Los argumentos del interlocutor de Darío resaltan la fragmentariedad de la técnica "representacional" moderna, su carácter instantáneo y fugaz opuesto a la permanencia del arte: "Ya no es en la carne, sino en el sistema nervioso, donde 
el pintor analista busca la definición escrita del personaje: y el personaje no entrega sino las variantes delicadas de su nerviosidad. No se pinta sino un instante de él. Su vida es demasiado matizada para que la condense un retrato" (Darío, 2006: 257). Asimismo, contra el cromatismo de la prosa dariana, se impone la paleta en blanco y negro - ampliada, a lo sumo, por los retoques con pintura - de la reproducción fotográfica: "La sombra, la luz, dos o tres grises, una nota obscura o rosada, y es todo el tema" (Darío, 2006: 258). Finalmente, se alega, con un cierto lenguaje técnico, que en la modernidad el retrato es capturado por efecto de la luz y no de la pintura ni de los aceites, como en otras crónicas suele referirse Darío a aquellos cuadros que le desagradan: "La luz se impone menos a los relieves de los seres, que lo que resalta de su vitalidad oculta; llega a ser una emanación psíquica, mucho más que una resultante natural de la óptica" (Darío, 2006: 258). De las seis imágenes que acompañan la crónica, ninguna refiere a los argumentos del interlocutor, sino todas, más bien, a las preferencias darianas; por lo que, más que ilustrar los juicios de una discusión, parecería que ocupan su lugar en el encadenamiento lógico. Esto es, sugieren una forma del pensar por imágenes.

La reproductibilidad técnica de la imagen actualizó las promesas democráticas de la modernidad. Hasta cierto punto, las revistas ilustradas relativizaban la necesidad de viajar hasta los museos metropolitanos en aras de la legitimación cultural, ya que ponían a disposición de cualquiera las grandes obras de arte. Darío fue siempre consciente del potencial pedagógico de estas reproducciones. Lo era en los años del Ateneo de Buenos Aires, cuando lideraba en la ciudad porteña el incipiente movimiento modernista, tal como cuando todavía trabajaba en El Correo de la Tarde en Guatemala. En Buenos Aires, al referirse a la circulación de cuadros de calidad en algunas ciudades en la época colonial, afirmó que sus artistas "tuvieron buenos modelos que ver, sin ir a Europa" (Darío en Caresani, 2015: 149). Antes, en Guatemala, había recalcado el gran favor que la Casa Griffin y Campbell le hacía al continente al publicar el libro ilustrado El Tesoro de Bellas Artes modernas (Darío, 1950: 632). A esto alude Graciela Montaldo cuando parafrasea a Walter Benjamin respecto del carácter "bizarramente democratizador de la imagen" (Montaldo, 2004: 40). Ante ellas todos somos expertos, ya que, en tanto código, se presentan como mucho más transparentes que el del lenguaje escrito.

Esta suerte de apertura indiscriminada, en algún punto, preocupaba a Darío. En el mismo artículo en el que celebraba la reproducción fotográfica de grandes obras de arte para su divulgación, se permite un reparo: "No da lugar, es cierto, a que el talento del grabador obre por su parte, no deja que quede realizada una manera personal de interpretación, ni permite a la mano hábil hacer su juego; pero la realidad sale gananciosa, el cuadro es exactamente reproducido, tal como lo ha concebido y ejecutado el cincel del artista creador" (Darío, 1950: 633). 
Parecería ser el mismo reparo que subyace en el diálogo de la crónica del 28 de mayo de 1903. No se trataría de una objeción a la fotografía en su calidad de recurso técnico, sino en cuanto experiencia estética devaluada. ${ }^{5} \mathrm{El}$ "narrador hiperestésico" (Caresani, 2018: 570), ante la reproducción técnica de una obra de arte, ve coartada su "manera personal de interpretación", así como inhabilitada su "mano hábil [de] hacer su juego" (Darío, 1950: 633). El "sistema sinestésico" (Buck-Morss, 2005: 183) del aturdido y abrumado lector de diarios tiene, ante la imagen técnicamente reproducida, una oportunidad desperdiciada de despertar los sentidos por la vía del arte. Constituye, apenas, otro estímulo inútil. La prerrogativa del cronista es, por el contrario, excitar el sistema sinestésico para propiciar esa experiencia.

Los medios disponibles en esta tarea son aquellos que amplíen los confines del arte. Tal como describe Caresani, el espacio que ocupa Darío en Buenos Aires es un "campo polémico", en el que las disputas estéticas se ven agudizadas por cuestiones generacionales, sociales e ideológicas (Caresani, 2015: 140). Entre los muchos proyectos en disputa, destaca la voluntad dariana de fundar una verdadera escuela crítica, cuya zona de influencia excediera las incipientes especificidades disciplinarias. En el centro de este campo artístico ampliado se ubica la literatura. Esa es la tutela literaria de la que habla Caresani y que abunda en ejemplos en las crónicas aquí estudiadas. ${ }^{6}$ La crónica periodística, más aún si son páginas de arte, y mejor si cuenta con ilustraciones, aparece como un lugar privilegiado para este fin. Una misma crónica condensa opiniones artísticas, literarias, políticas, históricas y, no menos importantes por el "contexto de lectura" (Louis, 2014: 43) del "Suplemento Semanal Ilustrado", opiniones sobre moda. Esto no se observa únicamente en las reseñas de los vernissages, sino que es incluido como una posibilidad del arte:

M. Carolus-Duran, y sobre todo en sus retratos, a pesar de que proclama su culto por Velásquez; antes bien es muy París y muy Rue de la Paix; diría a mi vez, Velásquez chez

\footnotetext{
${ }^{5}$ Usamos el término "estética" en el sentido que le da Susan Buck-Morss en su trabajo "Estética y anestésica: una reconsideración del ensayo sobre la obra de arte": "es una forma de conocimiento que se obtiene a través del gusto, el tacto, el oído, la vista, el olfato: todo el sensorium corporal. Las terminales de todos estos sentidos - nariz, ojos, oídos, boca, algunas de las áreas más sensibles de la piel - están localizadas en la superficie del cuerpo, la frontera que media entre lo interior y lo exterior. Este aparato físico-cognitivo con sus sensores cualitativamente autónomos y no intercambiables (los oídos no pueden oler, la boca no puede ver) constituye el 'frente externo' de la mente, que se topa con el mundo prelingüísticamente y que, en consecuencia, no sólo es previo a la lógica sino también al significado" (Buck-Morss, 2005: 173).

${ }^{6}$ Un caso análogo al referido por Caresani para detallar este mecanismo se encuentra en la crónica del 11 de junio de 1903. Dice Darío sobre un cuadro del Salón del Ateneo: "es un Grasset que ha leído Rollinat y es amigo de Des Esseintes" (Darío en Caresani, 2015: 141). Repite unos años después: "Merece el entusiasmo de Peladán, que evoca al gran Barbey, después de recurrir a Shakespeare" (Darío, 2006: 280).
} 
Paquin. Fuera de sus célebres facultades de color y de elegancia, M. Carolus-Duran se hace notar por sus cualidades de sastre. Y su "Dame en satin" se llamaría mejor "Satin en dame" (Darío, 2006: 276). ${ }^{7}$

No sin conflictos, la masificación del arte por medio de publicaciones ilustradas le representaba a Darío una oportunidad para ensayar sus hipótesis.

La antítesis de la primera de las crónicas es la tercera, igualmente dedicada al Salón de Bellas Artes (18 de junio de 1903). Esta última carece de imágenes, pero comparte con la segunda un recurso que Darío había usado y usaría de manera flexible en sus crónicas de arte: la subordinación de las secuencias descriptivas al criterio espacial de la división por salas visitadas en la exposición. En esas dos crónicas la separación es estricta. Resulta evidente que Darío tuvo poco control sobre el contexto de publicación de, al menos, la segunda de las crónicas, ya que de las cinco imágenes que la componen apenas dos son mencionadas en el texto. Poco tiempo separa la publicación de estas crónicas, sin embargo, el tono es completamente distinto al de la primera entrega. Al final, el desencanto de Darío por el arte expuesto es absoluto, y la crónica acusa la tarea de aquella crítica - con el riesgo de incurrir en aquello que señala - que se esmera en "trabajada[s] letanía[s] obligatoria[s] en los cuotidianos [sic] y revistas [que] dejan muy poco provecho estético" (Darío, 2006: 289).

Resulta llamativo el contraste entre las distintas entregas. Lo que las separa son las posibilidades que la reproducción técnica de la imagen le abre a la escritura. Si en la primera crónica el recurso dominante es el del diálogo y en la tercera el de la acumulación paratáctica, en la segunda - ilustrada, aunque a espaldas del textopredominan pequeñas ékfrasis orientadas a recomponer un sistema - fundado en referencias estrictamente personales - que la disposición de las salas habría atomizado. Dado que la oferta del salón es tan vasta que amenaza con anular al visitante ("Y hay en todas las salas un rumor de colmena y un ambiente de jardín - a pesar del polvo y la confusión" [Darío, 2006: 256]), el ojo experto del cronista se ve ante el reto de reconstruir las relaciones significativas y los rasgos diferenciales de cada una de las obras y de las salas. El cronista debe, frente a tal dispersión, garantizar de cualquier forma algún tipo de experiencia. La versión dariana de la ékfrasis desborda sus atribuciones clásicas, volviéndose así el principio rector de aquellos fragmentos en los que se la usa para "hablar por las imágenes, [para] hacer literatura a partir de ellas" (Caresani, 2015: 144). Cuando no es ésta la estrategia elegida, el ordenamiento sintáctico de las salas mitiga el zumbido de esa "colmena". Esto refuerza la tradicional caracterización

\footnotetext{
${ }^{7}$ Nuevamente, resuenan las teorías del interlocutor de Darío en la primera crónica: "Nunca se ha gustado más del rasgo sobriamente significativo, del estilo buscado en la actitud familiar, la definición del personaje por una gran línea decorativa, de inflexión según el contorno y que limita sin insistencia, con flexibilidad y encanto" (Darío, 2006: 258).
} 
del escritor modernista como sujeto privilegiado ante el bazar de la cultura, el cual opera como una guía a seguir en la constitución del buen gusto latinoamericano.

\section{Darío ante la fotografía}

En parte por la ampliación del campo artístico que propiciaron los modernistas, la nueva división del trabajo escriturario los ubicó en ese límite difuso entre la escritura literaria y la que hoy consideraríamos comercial, asimilando su figura autoral a la del fotógrafo, que se debatía entre el arte y la publicidad. Tanto el cronista modernista como el fotógrafo tuvieron que convencer al público - y, tal vez, hasta a sí mismosdel valor artístico de su trabajo. Sobre ambos pesaron los mismos prejuicios estéticos del siglo XIX. Darío, en uno de sus textos de la serie de fait-divers, "París. Hombres, hechos, ideas" (19 de junio de1902), escribe sobre la suerte de un fotógrafo ante los jueces del arte. Se trata de un fragmento dedicado a Edward J. Steichen, fotógrafo y artista norteamericano que había comenzado su carrera como publicista para continuarla como "fotógrafo artista". La crónica narra, con la clásica estructura del fait-divers, la conmoción que causaron unas fotos de Steichen expuestas en el Salón de la Société des Artistes Français. Según el cronista, era la primera vez que eso ocurría. La afirmación resulta falsa, ${ }^{8}$ pero lo cierto es que la crónica de Darío da cuenta de un fenómeno de borramiento de las fronteras entre las artes que resulta muy llamativo. Efectivamente, las fotos de Steichen fueron admitidas en el Salón, sin embargo, bajo el rótulo de grabados. ${ }^{9}$

De lo que se está dando testimonio aquí es del pictorialismo, movimiento estético que, por medio de la exageración de sombras y difuminados, aspiraba a otorgarle estatus artístico a las fotografias. Puede entenderse como otro capítulo de lo que Benjamin llamó la constante "justificación de la fotografia ante la pintura" (Benjamin, 1989: 65), que tuvo en el movimiento pictorialista al último exponente de una concepción de la fotografía que abonaba un imaginario mimético respecto a lo real. En

\footnotetext{
${ }^{8}$ Helmut Gernsheim afirma que los primeros acercamientos artísticos a la fotografía expuestos como tal son rastreables hasta la Great Exhibition of the Works of Industry of all Nations, la primera exposición universal, celebrada en Londres en 1851. En ese evento, el fotógrafo estadounidense John Edwin Mayall presentó una serie de diez daguerrotipos bajo el rótulo de "photographic fine arts" (Gernsheim, 1962: 73).

${ }^{9}$ Dice Darío: "Estos retratos parecían finísimos grabados antiguos. Pero la cuestión es que no eran tales grabados sino fotografias. 'No podemos aceptar fotografias'. 'Pero éstas son ciertamente admirables y del más puro arte' arguyó uno. 'Sentemos el precedente'. Se aceptaron, por primera vez, fotografías en el Salón, pero con el nombre de 'igrabados!'. En verdad esas fotografías de Maeterlink [sic], de Rodin, de otros, son obras maestras que nada tienen que ver con el 'photo' vulgar" (Darío en Caresani y Schmigalle, 2017: 111).
} 
el pictorialismo, la fotografía recibía exactamente el mismo tratamiento que una pintura, lo que confirma por defecto la concepción mimética del arte, ya que obstaculiza el desarrollo de aquélla en tanto discurso autónomo (Dubois, 1986: 30). Sin embargo, en el discurso de Darío se cuela una reflexión sobre la fotografía que la acerca a desarrollos posteriores de la teoría de la imagen. Él rescata las fotografías de Steichen por ese "algo más" que portan, eso que en palabras de Benjamin constituye una "chispita minúscula de azar, de aquí y ahora" (Benjamin, 1989: 67). Ésta es la concesión que Benjamin le hace a la fotografia, tras desestimarla por haber sido un arte de ferias posteriormente industrializada. Aquello que aparece apenas entrevisto por Benjamin - y que resuena en las referencias al sistema nervioso que domina en los retratos modernos según Darío - sería luego desarrollado por André Bazin en algo que se parece más a la concepción contemporánea de la fotografía, esto es, ni pura mímesis ni pura convención, sino huella y rastro de lo real. ${ }^{10}$

Así es como, inquieto, lo ve Darío. Por un lado, en Steichen, quien casualmente sería uno de los precursores de la fotografía de moda, algo que, sin duda, a Darío le hubiera encantado. Y, por otro, en las tarjetas postales, las cuales, en contraste con la opinión de otros "escritores" (las comillas están en el original), son rescatadas como un consumo cultural legítimo. Que eran distintas a las cartas, sí, no hay duda, pero la diferencia no le sirve a Darío para criticarlas, sino para cuestionarse por sus alcances. Primero, porque, por su naturaleza menos codificada, cualquiera podría enviar una postal, lo que llevaría a que la emoción de recibir una resultara algo mucho más habitual que la de recibir sesudas cartas. Y, segundo y más importante, porque la postal "es la ilusión de la presencia" (Darío, 2006: 240), si bien menos elocuente por las palabras, mucho más por la imagen del ser o el lugar deseado.

El proyecto de Steichen para dignificar la fotografía consistía en retratar a intelectuales y artistas europeos, como Auguste Rodin o Maurice Maeterlinck, por ejemplo. Darío lee este gesto y lo busca luego en los salones de Bellas Artes, siendo los retratos prácticamente lo único que le llama la atención, y lo que con más insistencia critica es si éstos no cumplen con el cometido de simular la presencia perturbadora de lo real.

10 "De ahí que la pintura no sea por lo tanto más que una técnica inferior del parecido, un ersat de los procedimientos de reproducción. Sólo el objetivo nos da del objeto una imagen capaz de calmar, en el fondo de nuestro inconsciente, ese afán de sustituir el objeto por algo mejor que un calco aproximativo: por el propio objeto liberado de las contingencias temporales. La imagen puede ser vaga, deforme, descolorida, sin valor documental, pero procede por su génesis de la ontología del modelo; es el modelo. De allí el encanto de las fotografías de álbum. Esas sombras grises o sepia, fantasmagóricas, casi ilegibles, no son ya los tradicionales retratos de familia sino la presencia turbadora de vidas detenidas en su tiempo vivido, liberadas de su destino, no por el prestigio del arte sino por virtud de una mecánica impasible; porque la fotografía no crea eternidad como el arte; sino que embalsama el tiempo, los sustrae únicamente a su propia corrupción” (Bazin, 1965: 5-6). 
Es eso lo que discuten Darío y su amigo en la primera crónica del "Suplemento". La experiencia de la imagen fotográfica parecería haber trastocado la percepción del retrato artístico que tiene un insatisfecho Darío en los salones de Bellas Artes. Como ya se dijo, la imagen reproducida técnicamente democratizó el lujo ${ }^{11}$ y el arte, lo que obligó a los artistas de la época a tomas de posición al respecto. En este sentido, es importante entender la extraña acepción de la palabra "democratización", ya que en su contexto estaba más asociada al concepto de mediocracia y de igualación para abajo que a lo que podríamos entender hoy. Los Estados Unidos representan la condensación de esto, por lo que la idea de que la innovación cultural vendría de allá era conflictiva. En su artículo sobre Steichen, apunta Darío: "Los yanquis, por más que se quiera desconocerlo, o que no se desea confesarlo, se van imponiendo 'también' en arte" (Darío en Caresani y Schmigalle, 2017: 112; las comillas son del original). Nuevamente, la incomodidad ante un campo sobre el que se quiere intervenir, pero que resulta impredecible.

Lo que vemos, entonces, es el desconcierto ante las derivas insospechadas de la experimentación cultural. Los medios en los que trabajó Darío propiciaron nuevas formas de lectura y consumo de objetos culturales. Para decirlo brevemente con Montaldo, se generó una forma de lectura basada en la "atención dispersa", un régimen muy distinto al de "prestar atención" (Montaldo, 2004: 41). Esta última responde a los mandatos de la cultura letrada, ya que deposita en la racionalidad la tarea de guiar la atención hacia un objeto específico. Esa lectura lineal y pragmática difiere de lo oblicuo y arbitrario del deambular dariano por los salones de la muestra. Su distracción, su atención dispersa, libera al "ojo sobrecargado con funciones de seguridad" (Benjamin citado en Buck-Morss, 2005: 189) y engendra una prosa dispuesta a jugar con las posibilidades de la imagentexto. ${ }^{12}$

Estos ensayos de cultura plebeya no eran, en palabras de Romano, ni contestatarios, ni críticos, ni de protesta, simplemente estaban "limitad[os] a satisfacer [...] deseos, gustos y tendencias que la cultura oficial, desde sus esquemas ideológicos li-

11 "A diferencia de sus predecesoras, las cartes de visite, las tarjetas postales ilustradas dan cuenta de una práctica viajera más extendida, menos elitista y más esnob. Si las cartas de visita transformaban el cuerpo retratado de su propietario en un objeto de intercambio, que atestiguaba un cierto recorrido y una sociabilidad restringida, la postal ilustrada corre del centro de la imagen a su emisor para convertirse en un vestigio - a su modo una reliquia - de una experiencia que no por ser comerciable deja de vivirse como subjetiva. Se trata, entonces, de una tímida democratización del lujo a la que ambos se pliegan también como consumidores" (Mendonça, 2017: 3).

${ }^{12}$ En otro de esos juegos con la imagentexto, en la crónica del 6 de junio de 1901, la profusión de ilustraciones altera, entre otras cosas, la regularidad de los títulos, ya que ésta no se trata de una reseña del Salón, sino de una crónica en el Salón. En "En el Salón” (06/06/1901), el lector tiene la impresión de, efectivamente, estar en el Salón junto con el cronista y los cuadros. 


\section{Luis Alberto Salas Klocker}

berales-positivistas, no podía comprender ni mucho menos admitir" (Romano, 2005: 167). Al anverso de la cultura burguesa se inauguran formas del placer en la lectura que no estaban contempladas por la esfera de lo oficial. Es así que Darío cierra una de sus crónicas haciendo una autocrítica sobre su anterior manera de escribir acerca de los salones de arte:

Luego he de volver a visitar despacio la vasta feria del color, y os diré mis impresiones. No seré minucioso, inútilmente minucioso como en otras ocasiones, en que os he enviado letanías de nombres y de cuadros. Vale más señalar las obras de mérito y daros una idea de las pocas obras maestras, que pasar una revista que no dejará ningún provecho, ni siquiera a título informativo, por la multiplicidad. Hasta pronto, pues (Darío, 2006: 260).

\section{Bibliografía}

BARTHES, Roland

"El mensaje fotográfico", en Cuadernos de Cine Documental. Buenos Aires: Universidad Nacional del Litoral, número 19 (junio 2016), 86-97.

Bazin, André

"Ontología de la imagen fotográfica", en Diálogos: Artes, Letras, Ciencias humanas. México: El Colegio de México, Centro de Estudios Históricos, volumen 2, número 1 [7] (noviembre-diciembre 1965), 3-6.

Benjamin, Walter

Discursos interrumpidos I. Filosofia del arte y de la historia. Buenos Aires: Taurus, 1989.

Buck-Morss, Susan

"Estética y anestésica: una reconsideración del ensayo sobre la obra de arte", en Mariano López Seoane (editor). Walter Benjamin, escritor revolucionario. Buenos Aires: Interzona, 2005, 169-222.

Caresani, Rodrigo

"El arte de la crítica: Rubén Darío y sus crónicas desconocidas del Salón de 1895 para La Prensa", en Anales de Literatura Hispanoamericana, número 44 (2015), 137-183.

"Darío, entre Whistler y Ruskin", en Carolina Bartalini y Rodrigo Caresani (editores). Actas del Congreso Internacional Rubén Darío: la sutura de los mundos. Sáenz Peña: Universidad Nacional de Tres de Febrero, 2018, 563-576.

Caresani, Rodrigo y Günther Schmigalle

Bibliografia de Rubén Darío en La Nación de Buenos Aires (1889-1916). Catálogo comentado y crónicas desconocidas. Managua: Dinámica, 2017. 


\section{Salones darianos: fotografía, arte y literatura en la crónica modernista}

DARíO, Rubén

España contemporánea. París: Garnier Hermanos, 1901 a.

Peregrinaciones. París: Librería de la Viuda de Ch. Bouret, 1901 b.

La caravana pasa. París: Garnier Hermanos, 1902.

Parisiana. Madrid: Librería de Fernando Fé, 1907.

Obras completas. Tomo I. Crítica y ensayo. Madrid: Afrodisio Aguado, 1950.

Escritos dispersos de Rubén Darío. Volumen II. Edición de Pedro Luis Barcia. La Plata: Universidad Nacional de La Plata, Facultad de Humanidades y Ciencias de la Educación, 1977.

España contemporánea. Edición de Noel Rivas Bravo. Managua: Academia Nicaragüense de la Lengua, 1998.

La caravana pasa. Libro cuarto y Libro quinto y último. Edición de Günther Schmigalle. Managua/Berlín: Academia Nicaragüense de la Lengua/Tranvía, 2004.

Crónicas desconocidas, 1901-1906. Edición de Günther Schmigalle. Managua/Berlín: Academia Nicaragüense de la Lengua/Tranvía, 2006.

Crónicas viajeras. Derroteros de una poética. Edición de Rodrigo Caresani. Buenos Aires: Facultad de Filosofia y Letras de la Universidad de Buenos Aires, 2013.

DuboIs, Philippe

El acto fotográfico. De la representación a la recepción. Barcelona: Paidós, 1986.

Gernsheim, Helmut

Creative Photography. Aesthetic Trends. 1839-1960. Nueva York: Bonanza, 1962.

LouIs, Annick

"Las revistas literarias como objeto de estudio", en Hanno Erlicher y Nanette Ribler-Pipka (editores). Almacenes de un tiempo en fuga: revistas culturales en la modernidad hispánica. Berlín: Shaker, 2014, 31-57.

Malosetti Costa, Laura

Los primeros modernos: arte y sociedad en Buenos Aires a fines del siglo XIX. Buenos Aires: Fondo de Cultura Económica, 2001.

Mendonça, Inés de

"Mansilla y Darío entre postales: ¿celebridad o esnobismo?", en Cuadernos LIRICO, número 16 (2017). Consultado en: http://lirico.revues.org/3678 [20/03/2020]. 


\section{Luis Alberto Salas Klocker}

\section{Mitchell, William}

Teoría de la imagen. Ensayos sobre representación visualy verbal. Madrid: Akal, 2009.

\section{Montaldo, Graciela}

"Culturas críticas: la extensión de un campo", en Iberoamericana. Pittsburgh: Universidad de Pittsburgh, año 4, número 16 (diciembre, 2004), 35-47.

Ramos, Julio

Desencuentros de la modernidad en América Latina. Caracas: Fundación Editorial El perro y La rana, 2009.

Romano, Eduardo

Revolución en la lectura. El discurso periodístico-literario de las primeras revistas ilustradas rioplatenses. Buenos Aires: El Calafate, 2005.

TeLL, Verónica

"Reproducción fotográfica e impresión fotomecánica: materialidad y apropiación de imágenes a fines del siglo XIX", en Laura Malosetti Costa y Marcela Gené (compiladoras). Impresiones porteñas. Imagen y palabra en la historia cultural de Buenos Aires. Buenos Aires: Edhasa, 2009, 141-164. 